\title{
Emergency and permanence of the Zika virus epidemic: an agenda connecting research and policy
}

\section{Emergência e permanência da epidemia do vírus Zika: uma agenda que conecta pesquisa e política}

\author{
Emergencia y permanencia de la epidemia \\ del virus del Zika: una agenda que conecta la \\ investigación y la política
}

\author{
Martha Cristina Nunes Moreira \\ Marcos Nascimento 1 \\ Corina Helena Figueira Mendes 1 \\ Marcia Pinto 1 \\ Sandra Valongueiro 2 \\ Maria Elisabeth Lopes Moreira 1 \\ Tereza Maciel Lyra 3 \\ Hannah Kuper 4 \\ SEIZ Research Group 5
}

doi: 10.1590/0102-311X00075718

Recently, the Zika virus epidemic has caused a setting of health emergency in Brazil. This event has mobilized several stakeholders to look at this reality - where women, men and children born with the marks of these diagnoses are differently affected - as one with vectors, illnesses and obscure diagnosis situations. Recalling this recent memory means summoning the political realms to demand the commitment to the health of the population in contexts of health emergencies and their repercussions in the daily life.

The Zika virus epidemic is characterized as a total social fact 1, precisely because it synthesizes several determinations about epidemic processes by combining factors of economic and social inequality and revealing processes of vulnerability. This situation triggers a chronology of events that establish and dismiss the emergency: in November 2015, the Brazilian Ministry of Health issued a National Public Health Emergency 2; in February 2016, the World Health Organization (WHO) classified the Zika virus epidemic as a public health emergency of international concern 3; in March 2016, the Protocol for Surveillance and Response to the Occurrence of Microcephaly Related to Zika Virus Infection 4 was published; in November 2016, the WHO no longer considered the Zika virus as an international emergency 5; and, in May 2017, the Brazilian Ministry of Health declared the end of the emergency 6.

These sequential events, responsible for inaugurating and ceasing emergencies, do not suspend the living experience: babies will grow up and need, in addition to rehabilitation services, nurseries and schools able to receive them; and parents and relatives will need to work and most likely will be burdened by their exhausting routines. The emotional vulnerability to which professionals and users of health system are submitted are equivalent within a chain of iniquities and search for knowledge. Moreover, this chronology delimits a process that risks sexual and reproductive rights in the name of securitization of epidemics 7, reinforcing fears and stigmatization.

If, on the one hand, international agencies and the Brazilian government position themselves and qualify emergencies, on the other, by anticipating them very closely, the scientific field - both clinicians and researchers - mobilizes itself for answers 8,9,10.

Given this context, the National Network of Specialists of Zika and Related Diseases (RENEZIKA), among others, and studies on the biological and social aspects had the initiative of coming forward in a cooperation between national and international researchers to investigate and propose articulations for action.
${ }^{1}$ Instituto Nacional de Saúde da Mulher, da Criança e do Adolescente Fernandes Figueira, Fundação Oswaldo Cruz, Rio de Janeiro, Brasil. 2 Universidade Federal de Pernambuco, Recife, Brasil. 3 Instituto Aggeu Magalhães, Fundação Oswaldo Cruz, Recife, Brasil. 4 London School of Hygiene \& Tropical Medicine, London, U.K.

5 Other members listed at the end of the paper.

\section{Correspondence}

M. C. N. Moreira Instituto Nacional de Saúde da Mulher, da Criança e do Adolescente Fernandes Figueira, Fundação Oswaldo Cruz.

Av. Rui Barbosa 716, 2o andar, Rio de Janeiro, RJ 22250-020, Brasil. moreira@iff.fiocruz.br 
Almost three years after the first diagnoses, the data collection from the Social and Economic Impacts of Zika virus infection in Brazil, carried out in Rio de Janeiro and Recife (Pernambuco State), covering the subjects and rural regions of both these capitals, is concluded. This research was coordinated by the Oswaldo Cruz Foundation (Fiocruz), the Aggeu Magalhães Institute (IAM), the National Institute of Women, Children and Adolescents Health Fernandes Figueira Fernandes Figueira (IFF), the Federal University of Pernambuco (UFPE) and the London School of Hygiene \& Tropical Medicine. In Rio de Janeiro, the research was based on two prospective cohort studies. In Recife, subjects were from case-control studies on microcephaly, being the cohort based on health services (primary and specialized care) and children with congenital Zika syndrome.

The qualitative data collection included 145 interviews in the metropolitan areas of Recife and Rio de Janeiro from April to November 2017, with participants distributed into five groups: health professionals from primary and specialized care, mothers of children with congenital Zika syndrome, other relatives involved in children's care (parents, grandparents and uncles/aunts), men and women at childbearing age, and pregnant women. Each of the groups was marked by peculiarities in the approaches, respecting regional differences.

The research also included a quantitative analysis through interviews with the primary caregiver of the child. Five questionnaires were applied to 215 participants in Recife and 271 in Rio de Janeiro. The measure of social support, understood as the resources available to people in situations of need was obtained through the Medical Outcomes Study (MOS) scale 11. The short form of the Depression, Anxiety and Stress Scale (DASS-21) 12 was used to evaluate depression, anxiety and stress symptoms. A third tool - The Pediatric Quality of Life Inventory (PedsQL) Family Impact Module 13 - was included to measure the impact of chronic conditions on the quality of life of households. Questions about postpartum contraception, emotions regarding pregnancy and possible changes in the affective relationship after the child's arrival were applied to respondents 14. To estimate the economic impact, the social cost to households and the costs of the Brazilian Unified National Health System (SUS) were used to calculate the cost of care.

To building a research design considering these differences meant working toward diversity. To perform an exploratory and strategic research, we exposed themes central to our interlocutors, such as sexual and reproductive health, prevention information, family arrangements and care. Assuming a research involved in social transformation, we built a critical knowledge that allowed us the formulation of policies. Our preliminary reflections are shown below.

After analyzing studies on disabilities and listening our interlocutors, we noticed that children with small heads are exposed to discrimination. However, other children, with nonvisible marks, and who can only be diagnosed by experts and clinicians' examination, are at risk of not being included from healthcare processes, such as follow-up, care and welfare programs. We must take into consideration how much children with visible disabilities can obscure the ones with nonvisible disablement and accentuate the importance of the former, who also depend on technologies. In addition, we must highlight and reflect on the rationale of care lines, which is the responsible for the poor relationships between primary and specialized care 15 .

Vaccines, repellents and mosquitoes become stakeholders 16 and agents of a State that fosters no trust and safety ${ }^{17}$. As for the sexual transmission of the Zika virus, we highlight the discourse which is permeated with a logical model that relates the Zika's transmission to the HIV's one.

The Internet is a locus where people search for information and establish new networks, streamlining communication and information. New and old models coexist in the sexual division of labor that naturalizes the conception that the innate women's place is at care. Paternal abandonment, though not confirmed, is announced in the statements.

The Zika virus epidemic causes suffering in the mental health field, affecting in different manners and degrees the subjects involved, such as health professionals, mothers and families, who deserve well-thought-out answers to this effect. The suffering of a family can meet the demands for rearrangement of care, work and conjugality. Thus, the promotion of reception and support in the scope of primary care with specialized training is urgent. Regarding the health professionals, the lack of knowledge about the consequences of Zika virus on pregnancy and its repercussions on children's 
lives become a source of suffering, to which promotion of institutional training devices that invest in exchanges, continuing education and production of articulation between research, teaching and services are required.

Finally, we must think more about the permanence of transforming and articulating life and politics, and less on the emergencies going in and out of agendas. The Zika virus epidemic can raise awareness of the other children with disabilities who also need care services but are currently neglected. These problems are not caused exclusively by the Zika virus epidemic, instead they refer to persistent inequities in health care and social, gender, class, racial and disability inequalities.

\section{Contributors}

M. C. N. Moreira, M. Nascimento and C. H. F. Mendes participated in the conception, writing of the article, critical revision of the intellectual content and final approval of the version to be published. M. Pinto and S. Valongueiro contributed in the writing of the article, critical revision of the intellectual content and final approval of the version to be published. M. E. L. Moreira, T. M. Lyra and $\mathrm{H}$. Kuper participated in the critical revision of the intellectual content and final approval of the version to be published.

\section{Other members of the SEIZ Research Group}

Ana Paula Melo, Maria do Socorro Velloso de Albuquerque, Camila Pimentel Lopes de Melo, Thalia Velho Barreto, Loveday Penn-Kenkana, Daniel de Souza Campos, Aline Ehtringer, Leticia de Paula Barros, Norma Gjorup, Clarissa Simas, Heidi Larson and Silke Fernandes.

\section{Acknowledgments}

Our funding was provided by the Horizon 2020, the European Union's Framework Programme for Research and Innovation, under the Zika Preparedness Latin American Network (ZikaPLAN) grant agreement n. 734584 of the United Kingdom's Department for International Development (DFID) and Wellcome Trust (206016/Z/16/A). We thank the Brazilian National Research Council (CNPq) and the Rio de Janeiro State Research Foundation (FAPERJ) for the funding of research productivity for the students M. C. N. Moreira and M. E. L. Moreira.

\section{References}

1. Mauss M. Ensaio sobre a dádiva. In: Mauss M, organizador. Sociologia e antropologia. Rio de Janeiro: Cosac \& Naify; 2003. p. 183-314.

2. Governo do Brasil. Governo aciona ações de emergência diante da alta de casos de microcefalia em PE. http://www.brasil.gov.br/ saude/2015/11/governo-aciona-acoes-deemergencia-diante-de-alta-de-casos-demicrocefalia-em-pe (accessed on 28/Feb/ 2018).

3. Nações Unidas no Brasil. OMS declara vírus zika e microcefalia "emergência pública internacional”. https://nacoesunidas.org/omsdeclara-virus-zika-e-microcefalia-emergencia-publica-internacional/ (accessed on 28/ Feb/2018)

4. Secretaria de Atenção à Saúde, Ministério da Saúde. Protocolo de atenção à saúde e resposta à ocorrência de microcefalia relacionada à infecção pelo vírus zika. Brasília: Ministério da Saúde; 2016.

5. Organização Pan-Americana da Saúde; Organização Mundial da Saúde. OMS declara fim da emergência de saúde pública Internacional, mas diz que resposta ao zika e suas consequências deve continuar. https://www.paho. org/bra/index.php?option $=$ com_content \& view $=$ article \&id $=5297$ :oms - declara-fim-deemergencia-de-saude-publica-internacionalmas-diz-que-resposta-ao-zika-e-suasconsequencias-deve-continuar\&Itemid $=812$ (accessed on 27/Feb/2018). 
6. Governo do Brasil. Ministério da Saúde declara fim da emergência nacional para zika. http://www.brasil.gov.br/editoria/ saude/2017/05/ministerio-da-saude-declarafim-da-emergencia-nacional-para-zika (accessed on 27/Feb/2018).

7. Ventura DFL. Do Ebola ao Zika: as emergências internacionais e a securitização da saúde global. Cad Saúde Pública 2016; 32:e00033316.

8. Diniz D, Brito L. Epidemia provocada pelo vírus Zika: informação e conhecimento. RECIIS (Online) 2016; 10:1-5.

9. Fleischer S. Segurar, caminhar e falar: notas etnográficas sobre a experiência de uma "mãe de micro". Cadernos de Gênero e Diversidade 2017; 3:93-112.

10. Scott RP, Quadros MT, Rodrigues AC, Lira LC, Matos SS, Meira F, et al. A epidemia de Zika e as articulações das mães num campo tensionado entre feminismo, deficiência e cuidados. Cadernos de Gênero e Diversidade 2017; 3:7392.

11. Sherbourne CD, Stewart AL. The MOS social support survey. Soc Sci Med 1991; 38:705-14.

12. Vignola RCB, Tucci AM. Adaptation and validation of the depression, anxiety and stress scale (DASS) to Brazilian Portuguese. J Affect Disord 2014; 155:104-9.
13. Scarpelli AC, Paiva SM Pordeus IA, Varni JW, Viegas CM, Allison PJ. The Pediatric Quality of Life Inventory ${ }^{\mathrm{TM}}$ (PedsQL ${ }^{\mathrm{TM}}$ ) family impact module: reliability and validity of the Brazilian version. Health Qual Life Outcomes 2008; 6:35.

14. Aquino EML. Menezes GMS, Barreto-de-Araújo TV, Alves MTA, Alves MCC, Valongueiro $S$, et al. Avaliação da qualidade da atenção ao aborto: protótipo de questionário para usuárias de serviços de saúde. Cad Saúde Pública 2014; 30:2005-16.

15. Moreira MCN, Albernaz LV, Sá MRC, Correia RF, Tanabe RF. Recomendações para uma linha de cuidados para crianças e adolescentes com condições crônicas complexas de saúde. Cad Saúde Pública 2017; 33:e00189516.

16. Latour B. Reagregando o social: uma introdução à teoria do ator-rede. Salvador: Edufba; 2012.

17. Silva ACR, Matos SS, Quadros MT. Economia política do Zika: realçando relações entre Estado e cidadão. Revista Anthropológicas 2017; 28:223-46. 